\title{
Evaluation of investment attractiveness of a region as a guarantee for leadership in the territorial socio-economic development
}

\author{
Ruslan Skupskyi \\ Mykolaiv Interregional Institute for Human Development, \\ Higher Education Establishment "Open International University of Human Development "Ukraine" \\ 2nd Viiskova str., 22, 54003, Mykolayiv \\ Ukraine \\ e-mail: skuruslan@gmail.com \\ Ruslan Zubkov \\ Mykolaiv Interregional Institute for Human Developmene \\ Higher Education Establishment "Open International University of Human Development "Ukraine" \\ 2nd Viiskova str., 22, 54003, Mykolayiv \\ Ukraine \\ e-mail: zubkovruslan@ukr.net \\ Inga Shapovalova \\ Mykolaiv Interregional Institute for Human Development \\ Higher Education Establishment "Open International University of Human Development "Ukraine" \\ 2nd Viiskova str., 22, 54003, Mykolayiv \\ Ukraine \\ e-mail: Shapovalova@ukr.net
}

\begin{abstract}
Effective assessment methodology of the investment climate of a country or region is a guarantee for the continuous socio-economic system development, provided by integrated approach in establishing the environment for their qualitative development and creation of a positive image. The purpose of this article is to examine the investment attractiveness of a region as a basis for effective territorial socio-economic development, relying on a critical analysis of the current methodological approaches of determining the investment attractiveness of the regions of the country and their investment efficiency.

Our examination of investment processes in regions and a critical analysis of the results allowed to justify the following features (investment climate tends to deteriorate in recent years; there is instability in relation to the processes of attracting investments into the country; excessive differentiation in distribution of investments by regions remains stable) and to identify the main reasons of unsatisfactory investment activity in regions.
\end{abstract}

\section{Introduction}

The ongoing processes of dynamic globalization and technological challenges as well as the decentralization of public administration have greatly increased the significance of individual national regions, which, as a consequence, acquired new qualities, in particular, 1) the status of the entities that set their own development strategies; 2) strengthening of competition for leadership in socio-economic development, where the basis is the effective attraction and use of various types of capital, in particular, investment capital, etc. The increasing competitiveness of the regions requires to specify distinct government priorities in investment policy of regional development by improving investment climate, defining promising sectors of economy, reconciling interests of state, region, financial institutions and business entities in relation to directions and means of transformation of investment resources, etc. (Czyżewski et al. 2015; Zatonatska 2016; Cieślik et al. 2016; Brodzicki 2016; or Mishenin et al. 2018).

The study of regional economic development, in particular regional aspects of evaluation of investment attractiveness of areas has become widespread internationally. Researches of economic development of certain regions are conducted in many countries throughout the world. In the United States, for instance, indexes showing and yielding the ratings of the states on certain criteria and different tendencies - political, economic, environmental - are regularly published (see e.g. Radovic et al. 2017; or Newbery et al. 2018). Various consulting companies and economic publications systematically track information relating to situation in national and regional investment complexes from public sources and ratings of investment attractiveness of the regions, which are constantly being published by Standard \& Poor's, Moody's Investors Service i Fitch, IBCA, etc. 
However, a significant amount of scientific researches, which define the main features and aspects of regional investment attractiveness of the territories of Ukraine, leave the problem of systematic assessment of its constituent elements, in particular introduction of statistical tools for analysis and coordination of quantitative and qualitative constituents of evaluation model, insufficiently explored (Ragulina et al. 2018).

\section{Literature review}

Formation of the appropriate investment climate in the conditions of the newest market transformations causes the urgency of the task of developing universal adaptive and operational methodological approaches to assessment and monitoring of the investment attractiveness of individual regions. Investment potential and available resource potential of the regions of Ukraine determine the conditions for introduction of the economicmathematical method of regional assessment and monitoring of investment climate by the level of investment potential (Kharlamova, 2014), the degree of investment risks, existing experience of preliminary investment activity, based on introduction of territorial investment marketing (Reiff et al. 2016).

The increasing competitiveness of the regions requires to specify distinct government priorities in investment policy of regional development by improving investment climate, defining promising sectors of economy, reconciling interests of state, region, financial institutions and business entities in relation to directions and means of transformation of investment resources, etc. (Zatonatska 2016).

A complex and systematic research is relevant in this context, as well as the development of a methodological approach, which would meet the needs and interests of foreign investors, would be understandable for them and would provide internal users with comprehensive information.

In its turn, introduction of a special methodology deserves attention; this methodology should be based on factors of various levels and stages of development of socio-economic systems in the process of studying of aspects of formation of investment attractiveness of regions through the identification and substantiation of negative and positive tendencies of investment activity of business entities, as well as of strategic priorities of regional socio-economic development, which should be appropriately taken into account when developing strategies and integrated programs in relation to formation and support of a favorable investment environment (Blahun et al. 2017).

The existing processes of Ukraine's integration into the European economic space have already proved that one of the main conditions for achieving compliance with international standards of economic relations, in particular of EU countries, is the formation of a favorable investment climate. In view of this and in order to achieve high rating indices, the issue of regulation of legal and regulatory provision of investment activity at the legislative level, in particular through relevant institutions, low tax rate, transparency of business conduct, etc., becomes crucial. Thus, the lack of consistency between measures envisaged by law and real measures, an unstable monetary unit, an unpredictable political and economic situation, and the complexity of doing business, as revealed by the monitoring of Poland's investment attractiveness, made it possible to identify the main differences and problems of introduction of adapted mechanisms for attracting investment between the European countries and Ukraine (Ponomarenko et al. 2018). Considering the East Asian model, important components of formation of investment climate of state/region include: weakening of currency; stimulation of domestic consumption and investment; provision of a relatively low level of domestic prices compared to prices in USA and among the leading Asian exporters of industrial products; harmonization of the country's legislation with WTO requirements, etc. (Ziyadin et al. 2017).

Considering the aggregate and systematic nature of existing problems, the introduction of organizational and economic tools for management of investment processes at the regional level, the question of improvement of methodological approaches of such management arises. One of the directions is introduction and support of strategic planning of investment development (investment process) of regions, taking into account general macroeconomic trends and characteristic features of investment activities on particular territory (Zakharin 2016).

The main basis of the regional investment development strategies should be the improvement of quality of life owing to effective structural changes in economy and increasing competitiveness of the regional economic system based on the rapid increase of volumes and better structuring of investments, intensification of innovation activity, economy transition towards the innovative model of development and opening of high-tech manufacturing units, etc. (Litovkina 2015).

A critical analysis of current methodological approaches of determination of the status of regional investment attractiveness allows us to conclude that the definition of an index according to the criteria that determine the investment environment should be made on the basis of a systematic study of investment processes and a comprehensive search for the directions of their activation and strategic development. It is necessary to introduce a comprehensive model for assessment of investment climate of the state/region, creating favorable conditions for its formation. (Vakulich and Kliuchnyk 2018). 


\section{Methodology}

We employed interviews with Likert scale, as well as other methods involving indicators and their assessment. Moreveor, in our research process we attempted to link two sets of indicators: investment activity (increase in investment) and the socio-economic effect of their attraction (increased wages, reduction of unemployment, job creation, increase in retail trade, housing construction, growth of services rendered, reduction of mortality, improvement of health care, etc.). But success of investment activity in a region and effect of attracted financial resources for local community can be measured if only these sets of indicators are compared. The proposed methodology for calculation of the rating of investment efficiency in the Black Sea regions eliminates such disproportion by defining a set of criteria, indicators and a calculation algorithm.

A criterial analysis was introduced in the course of the study. It allowed to determine the efficiency of attractment of investments in the development of the Black Sea region of Ukraine in the context of increasement of the well-being of territorial communities in the retrospective dynamics:1) criteria determining investment activity of a region (city); 2) criteria determining the socio-economic effect of investments. The required data is provided by the State Statistics Service of Ukraine (2018), the State Employment Service, and are taken from other official sources as of the relevant reference date.

\section{$4 \quad$ Results and discussion}

The increase of basic macroeconomic factors of social development, and, consequently, both the quality of life of the population, and the development of foreign economic activity and cross-border cooperation with foreign partners, depend on the economic growth rates of the country or a region. Attraction of investments to the country, modernization of management and investment activities, development and implementation of efficient regional investment policy, aimed at increasement of the level of investment attractiveness and competitiveness of the regions, are fundamental in the market transformation and stable development of Ukrainian economy.

In the environment of urgency and limitation of investment support, the question of estimation of the increase of regional investment attractiveness as a criterion that gives potential investors the opportunity to form an opinion on the state of the investment object, substantiate the conclusion on the reliability of future investment and the right to receive profit from their investment, is actual. (Zubkov 2017).

According to the data provided by top-managers of the groups of companies of the European Business Association (EBA) working in Ukraine, the Index of Investment Attractiveness of the country has increased to 3.15 points on a 5-level scale and for the first time since 2011 left a negative zone, surpassing the mark of the level 3. According to the noted experts, such growth leads to some weakening in the entrepreneurs' negative attitudes, noting positive trends that have been caused by development of electronic services, simplification of permitting procedures for construction, reduction of the number of inspections of business entities, transparency of government procurement system, etc. Whereas, according to the representatives of business community, anticorruption programme, judicial and land reforms remain among the vital problems. Slow process of reforms, high rates of financial and credit services for business, armed conflict in the Donetsk and Luhansk oblasts, bureaucracy, contraband and shadow economy were also named among the negative factors.

At the same time, the study of the processes of domestic entrepreneurship development by the end of 2016 indicates its unfavorable character. 67 percent of respondents agreed with that, though in the first half of the year the respective figure was 78 percent. Another 23 percent of respondents noted that investment climate was neutral and remained unchanged. And only 2.2 percent of respondents considered business environment extremely favourable. Comparing investment climate in the first and second half-year periods of 2016, 46 percent of top-managers of companies-members of Association noted that it remained unchanged with neither improvement nor significant deterioration observed. Most respondents (48 percent) remained convinced that business environment in the first half-year period of 2017 would also remain at the same level, however, 34,9 percent of respondents expected an improvement. Almost 30 percent of top-managers would not advise their colleagues to plan investment projects in January-June of 2017, and 12 percent were strongly against that. On the other hand, 22,5 percent considered investments to be worthwhile, and 4,5 percent were optimistic about the idea of starting investment projects in that period.

According to experts from international investment organizations and funds investing in the countries of Europe, Middle East and Africa, and also according to the data of the publisher Institutional Investor, Ukraine is one of the most attractive countries for potential investments, specifically, as is emphasized by Union Investment, its agrarian sector. In September 2017 in order to determine potential investments a total number of 214 fund managers in 154 companies worldwide were interviewed about which country was ranked first in their list of business trips in the next 12 months. At the same time, 32 percent of investors considered Ukraine to be a primary country for a visit to explore business potential. At the same time, they and experts of Union Investment believed, that the most attractive investment industry in Ukraine was agrarian sector. 
A significant difference in the investment attractiveness of regions, which is synergistically formed under the influence of both national and regional level factors, is determined by the peculiarities of the geographical location and the unevenness of the socio-economic development of administrative units.

In the course of research of existing methodological approaches of evaluation of investment attractiveness of the regions, we have calculated the index of investment attractiveness of Ukrainian regions, including Black Sea area, according to methodology, proposed by Slobodianiuk (2016) which is based on such indicators as the ratio of the volume of industrial production (Vip), the number of enterprises and organizations (Neo), numbers of economically active population (Neap) and fixed capital investments per capita (Ic). Despite numerous scientific studies, the system of economic and statistic indicators of assessment of investment attractiveness of regions requires improvement and adaptation to existing conditions, in particular, in its compliance with the current system of national statistical reporting.

Investment attractiveness against a background of transformation of internal and external market relations is the basis for the formation of effective regional investment potential. Unfortunately, the significant experience of studying the problems of formation and volatility of investment attractiveness of the region, representatives of various economic schools do not give grounds for building of a unified approach to understanding the essence and interpretation of this complex economic category (Sydor 2015).

In scientific studies, we may quite often view the attempts of certain authors to define the investment attractiveness such as: 1) correspondence between a region and investor's main aims, which include profitability, risks avoidance and liquidity of investments; 2) level of satisfaction of investor's financial, industrial, organizational requirements and interests within a certain region; 3) situation in a region at a certain point of time, its development trends, which are reflected in investment activity (Asaul 2004).

After having conducted the monitoring on scientific views about the interpretation of the economic category given, from the view of investment climate, level of investment infrastructure development, possibility of attraction of investment resources and other factors, which profoundly influence on the formation of investment profitability and investment risks, we could establish our own definition for the investment attractiveness. It is an integral indicator, which is calculated with the help of a certain range of criteria (formal and informal ones), parameters and characteristic features of a regional socio-economic system, which define the expediency of investing the capital in an investment object, with the aim of satisfying investor's financial, productive, organizational and other needs or interests to a relevant extent.

It can be concluded that investment attractiveness of a region actually reflects the quality of a certain set of parameters and characteristics of the regional socio-economic system, while the comprehensive indicator (hereinafter index) of regional investment attractiveness is a relative assessment of this quality.

Such index, in our opinion, has to perform the following tasks:

- to determine the state of investment attractiveness of the regions of Ukraine for potential investment and prolongation of what is already being implemented;

- to help the government to detect problems, which impede the investment process on a regional level;

- to help local authorities to identify factors, which affect investment attractiveness of a region (oblast) as compared with other regions (oblasts), and the influence of which should be either intensified or minimized.

The primary basis of research of investment attractiveness of a region is the formation of a system of statistical and economic indicators of such an evaluation, which, along with the objectivity and informativity, would be adapted to the latest market transformations.

The development of a methodological approach to the definition of a regional index of investment attractiveness is a rather difficult task due to the following reasons, in particular: 1) inability to distinguish the regional component of the investment environment from the national one; 2) problem of combining data of quantitative and qualitative statistics in one indicator; 3) difficulty in combining the factors of evaluation of universal nature with the specific factors of assessment (for peculiar fields) in one indicator, etc. In doing so, it is also necessary to take into account a number of specific points, in particular: 1) system of factors assessed must not so much influence the region's economic environment, rather than influence the investor's decision on investing financial and other resources in a certain area; 2) an important thing is demarcation between factors, which undergo countrywide influence (such as tax legislation, customs regulations) and those, which are limited by a certain region (the level of human capital development, transport network); 3) statistics indicators that form the index have to be accurate and describe the phenomenon or the process as clearly as possible, and they must have a vivid interpretation as well.

Calculation of the index of investment attractiveness in the context of administrative units of the Black Sea area (according to the Institute for Economic Research and Policy Consulting 2014) indicates the leadership of the Odessa oblast, with the index of 1.468, which occupies the 1st place in the regional rating and the 3rd place in the national rating, whereas the Mykolaiv and Kherson Oblasts hold the 16th and the 21st places with indexes of 1.332 and 1.283 respectively

Considering gradation of factors according to a time changeability/unchangeability criteria, the Odesa oblast is considered an area with a high investment attractiveness rating for investors - the 3rd place as to 
unchangeable factors of the national rating and the 5th as to changeable factors, having 1.494 (the highest index is 1.521 for the Kharkiv oblast) and 1.425 indexes respectively.

In contrast to the Odesa Oblast, the Mykolaiv Oblast in the hard factors rating holds the 10th position (with an index of 1.398), and the 19th place (1.263), which is near the Kherson Oblast in the soft factors rating. The Kherson Oblast has low indexes of 1.336 and 1.197 (the 21st and 23rd places) respectively. Such level of the investment attractiveness for the regions mentioned in the study is rather low, which does not correspond to a current production and resource potential and strategic priorities of development. This, in its turn, negatively affects the formation of investment climate.

With the aim of further improvement of the investment supply of the Black Sea area, we have conducted a research devoted to investment attractiveness of the Mykolaiv, Odesa and Kherson oblasts. An interview method with top-managers of 225 domestic enterprises, which was based on a critical analysis of operating conditions of enterprise entities on micro- and macrolevels, strengths and weaknesses of production activity and identification of the degree of risk of investment activity, etc., was used. The research results allowed to substantiate the following conclusions, which determine the investment attractiveness of a region on the whole: i) Investment activities of the enterprise; ii) Market conditions; iii) Region attractiveness for start-up and business development; iv) Sources of regional competitive strengths; v) Constraining factors of production expansion; vi) Infrastructure development; vii) The investment efficiency of regional authorities; viii) Access to financial crediting in a region; ix) Regional economics; x) Innovations; xi) International integration; xii) Activity of licensing centers and administration services.

At the all-Ukrainian level, 66 percent of the surveyed heads of enterprises and organizations did not use the services of licensing centers (LCs) or the administration service centers (ACCs). The main reasons for this were: 1) no requirements for their services (48 percent of those who did not use services); 2) lack of sufficient information regarding the services of LCs/ACCs (22 percent); 3) low performance in comparison with competent authorities (14 percent); 4) the absence of such centers in the district/city (10 percent).

Unfortunately, the percentage of the enterprises-respondents that did not use the services of licensing centers and ACCs services in the Odesa and Kherson oblasts remains rather high (64.0-67.1 percent) and while compared to the Mykolaiv Oblast (23.0 percent), seems to be differentiated. Therefore, first of all, the issues of the cost of licensing centers and administration service centers services and corruption require to be settled.

The determining aspect of implementing the model of the country's sustainable economic development and creating its positive image on the world scene is substantiation and concentration of both national and regional socio-economic policies on the potential for investment and innovation development sectors of economic activities. Thus, in the short-term period:

- 65.1 percent of experts in investments and management of national projects in Ukraine believe that in the regional dimension potential investors might be interested in agriculture;

- 39.8 percent of respondents see investment perspectives in tourism, in particular, green tourism;

- 20.6 percent of respondents consider engineering industry to be a potentially attractive branch for investment;

- 15.6 percent of experts have reckoned electricity-producing industry, including alternative energy forms, to be among promising sectors;

- the potential investment attractiveness of food industry and the development of infrastructure has won 12.0 percent of convinced experts each, especially the marine complex, including sea farming;

- among other branches that might be of interest to investors in the regions, they named information technologies, woodworking and mineral industries, logistics, transport and construction.

Indeed, starting from 2014 a change in investors' preferences is being observed. Loss of industrial areas as a result of the escalation of the armed conflict in eastern Ukraine, the change in products markets and demand within the country led to manufacturing industry reorientation to the agrarian sector. During 2014-2016, capital investment in the agro-industrial complex (AIC) expressed in terms of money grew by 2.7 times: from 18.6 billion hryvnias in 2013 up to 50.5 billion hryvnias in 2016. In the context of the regions in the Black Sea area, according to the results of 2017, the largest volume of capital investment in agro-industrial complex is observed in the Kherson Oblast, at the level of 2079.2 million hryvnias.

Among the main reasons providing investment incentives in domestic agrarian sector should be named: sustained growth of demand for agricultural products, reduction of risks in comparison with anticipated ones at the commencement of hostilities, impact of reforms, ability to diversify product markets, high level of investment attractiveness and sales of agricultural food products, etc. (Skupskyi and Anikieieva 2016; Mantsevych et al. 2016).

The results of the research of the regional investment attractiveness (the northern coast of the Black Sea was taken as an example) allowed to justify the following conclusions: 1) the investment climate in the regions of Ukriane tends to deteriorate significantly within recent years; 2) the investment process in the country tends to 
be unstable: after capital investment increase in almost all regions (2003-2012, with the exception of 2009), their amount has begun to decrease since 2013) there is excessive differentiation in distribution of investments among the regions of the country. Investments are mainly concentrated in economically developed regions with a short payback period. Among them are the regions with high concentration of heavy industry and regions with recreational potential; 4) inadequate level of investment activity of regional economic entities is caused by: complicated procedures relating to the entry of foreign investments; lack of confidence in stability of government policy and effectiveness of reforms; government intervention in private business activities; significant administrative obstacles to the development of investment activity; high levels of corruption of bodies of power, armed conflict in the East of Ukraine, etc.

Aiming to determine the effectiveness of investment processes in a certain region of the country in 20162017, we conducted a research of regional investment efficiency (the Donetsk and Luhansk oblasts were not included) basing on the data of the rating agency 'Euro-Rating'. The final rating is based on two-component evaluation of results: investment activity (capital investment, foreign investment and construction), and the socio-economic impact of investments (wages, housing commissioning, employment assistance and services rendered). In this context, the achieved socio-economic effect demonstrates the degree of success of raising funds and their impact on welfare of the local community.

At the beginning of observation, a group of leaders with the rating exceeding 180 points (rating ineA and ineV) included the Dnipropetrovsk, Kyiv, Lviv, Mykolaiv, Odesa, Poltava and Kharkiv oblasts. During the specified period significant changes occurred. Basing on its results the Mykolaiv Oblast can be referred to leaders only provisionally, since the region has recently been showing low results. Thus, for the period 20162017 the Mykolaiv Oblast lost 39 points, ending at the mark of 147 points. If it does not raise its score to 180 points or more in the next period, it will be excluded from the group of leaders. In its turn, the Kherson Oblast with 136 points got the rating IneE - below average. Unfortunately, in comparison with leaders the results of outsiders are characterized by significant quarterly fluctuations.

The obtained result can be treated as an indirect evaluation of performance efficiency of the socioeconomic functions by local authorities. This approach allows to identify areas with persistently high investment efficiency, which, in its turn, can prove the existence of successful business practices in the region. It also highlights the areas where the investment efficiency should be increased, perhaps by reviewing strategic and managerial decisions. In addition, the rating assessment can be an indication of quality of local authorities' performance, etc., for general public. The highest growth of investment efficiency at +26 points is shown by the Odessa Oblast with an average score of 201.8 points for 2 years, what corresponds with the maximum level IneA (Table 1).

Table 1. Rating of investment efficiency of the regions of the Black Sea area in 2016-2017, quarterly (in points)

\begin{tabular}{|c|c|c|c|c|c|c|c|c|c|c|}
\hline \multirow{3}{*}{$\begin{array}{c}\text { Oblast, region, } \\
\text { country }\end{array}$} & \multirow{2}{*}{\multicolumn{4}{|c|}{$\begin{array}{c}\text { year } 2016 \\
\text { Quarter }\end{array}$}} & \multicolumn{4}{|c|}{ year 2017} & \multirow{3}{*}{ 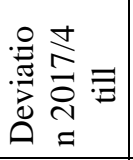 } & \multirow{3}{*}{ 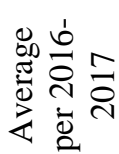 } \\
\hline & & & & & \multicolumn{4}{|c|}{ Quarter } & & \\
\hline & 1 & 2 & 3 & 4 & 1 & 2 & 3 & 4 & & \\
\hline Mykolaiv & 186 & 192 & 197 & 192 & 166 & 148 & 132 & 147 & -39 & 170,0 \\
\hline Odesa & 176 & 215 & 224 & 200 & 210 & 196 & 191 & 202 & +26 & 201,8 \\
\hline Kherson & 171 & 156 & 120 & 107 & 93 & 118 & 142 & 166 & -5 & 134,1 \\
\hline Black Sea area & 177,7 & 187,7 & 180,3 & 166,3 & 156,3 & 154,0 & 155,0 & 171,7 & -6 & 168,6 \\
\hline Ukraine & 160,3 & 161,0 & 159,0 & 162,9 & 160,8 & 161,0 & 161,0 & 161,0 & $+0,7$ & 160,9 \\
\hline
\end{tabular}

In general, the investment efficiency of the regions in the Black Sea area is estimated as IneC - above average with the mark of 168.6 points, which is somewhat (by 7.7 points) above the average all-Ukrainian index.

The first of two components of the investment efficiency rating is the evaluation of investment activity of regions, which determines how successful is the region's investment policy in comparison with other territorial units, and how its indicators change in dynamics. For nine months in a row in 2017 the Odesa Oblast occupies a leading position according to the evaluation of investment activity. The region is characterized by high growth rates and high average values of individual indicators. On each of the three indicators (capital investments, construction work, foreign investments) the Odesa Oblast has not dropped below 13 position. In our opinion, the main reason of this is the revitalizing of maritime economic complex, construction industry and agriculture. More than 50 percent of attracted capital investments are directed to these sectors.

A successful socio-economic policy should become a factor that allows the region to compensate losses in attracted investments. Like any other financial assets, investments should provide a return. In the field of economic relations and entrepreneurship a return is a profit in the first place, while for a region it is the solution 
of socio-economic problems, like employment growth, increase of wages, improvement of living conditions, etc. Therefore, while determining socio-economic impact from the investments, one should take into account such indicators as wages, employment assistance, new housing supply, volume of services rendered. The calculation of these indicators is carried out in the same way as in the assessment of investment activity, with one exception: employment assistance.

Regions that actively cooperate with investors for a long period of time obtain the highest socio-economic impact, in particular, the Poltava, Odesa, Dnipropetrovsk and Kharkiv oblasts. The Mykolaiv Oblast, in its turn, after holding the leading positions for a long period of time according to the investment activity indicator, showed lower results in 2017. It indicates the circumstances, in which all the investments in the region had never provided benefits in the form of improvement of the key socio-economic indicators.

\section{Conclusions}

According to our study of the domestic business climate in 2016-2017, the majority of respondents noted that it remained unfavourable. The negative factors also include slow process of reforms, excessively high rates of financial and lending services for business, armed conflict in eastern Ukraine, bureaucracy, contraband and shadow economy.

Our results allowed to justify the following conclusions in the context of the criterial blocks, in particular: investment activity of an enterprise, market conditions, attractiveness of regions for start-up and development of business, sources of competitive advantages, factors limiting the increase of production, infrastructure development, education and human resources, efficiency of performance of local authorities (in the investment process), access to funding, regional economics, innovations and international integration, etc.

On the basis of a thorough study, it was found that the Odesa Oblast is ranked the first in the regional rating with the index of 1.468 , and occupies the third position in the national rating, whereas the Mykolaiv and Kherson oblasts occupy the 6th and the 21 st positions (1.332 and 1.283 respectively). Among the pressing problems of attraction of investment resources that require an urgent solution from the government are crackdown on corruption, judicial and land reforms, pace of reforms, excessively high lending rates for business, armed conflict zone, bureaucracy, contraband and shadow economy. The loss of industrial territories as a result of escalation of armed conflict in eastern Ukraine, interchange of sales markets and domestic demand have caused investors to refocus from industrial to agrarian sector. In 2014-2016, capital investments in agrarian sector rose in monetary terms by 2.7 times to 50.5 billion hryvnias; in particular, in the Kherson Oblast they rose to 2079.2 million hryvnias. The research identified the following important reasons which stimulate investment in agrarian sector: stable growth of demand for agricultural products, the impact of reforms, the ability to diversify product sales markets, high levels of investment attractiveness and sale of agricultural food products.

Rating assessment of territorial units of Ukraine was developed with the aim of evaluation of results from attracting investments into regional development basing on the research of investment efficiency. According to this assessment the Mykolaiv and Odesa oblasts are among the leading regions with the indicators above 180 points, that corresponds to the ratings IneA and IneB. In 2016-2017 the Odesa Oblast had the greatest increase by +26 points with the average value of 201.8 points (IneA), whereas the Mykolaiv Oblast lost its positions ( -39 points) to the average level IneD (147 points). The Kherson Oblast (136 points) obtained rating IneE - below average.

Research of regional investment processes and the critical analysis of the obtained results allowed to specify the following features (investment climate tends to deteriorate within recent years, while investment entry processes in this country are characterized by the lack of stability; there is a great differentiation between regions in relation to investments distribution) and identify the main reasons for the lack of investment activity, among which are the complicated procedures relating to the entry of the foreign investments to the country, low confidence in stability of government decisions, lack of effective reforms, government intervention in private business activities, high level of corruption and significant administrative barriers to the development of investment activity, unhindered passage of permit documents for investment projects, armed conflict in eastern Ukraine.

\section{References}

Asaul A (2004) Systematyzatsyia faktorov, kharakteryzuiushchykh ynvestytsyonnuiu pryvlekatelnost rehyonov [Systematization of factors characterizing the investment attractiveness of regions]. Rehionalna EkonomikaRegional Economy 2: 53-62 
Blahun I, Dmytryshyn L, Leshuk H (2017) Cognitive approach to analysis of investment attractiveness of the regions. Scientific bulletin of Polissia 4 (12) P1: 171-176. doi: 10.25140/2410-9576-2017-1-4(12)-171-176

Brodzicki T (2016) Does variety matter? Export pattern of Poland prior and after the accession to the EU. International Economics Letters 4(2):103-118. doi: 10.24984/iel.2016.4.2.5

Cieślik A, Michałek J, Mycielski J (2016) Globalization, international trade, and human development: a case of Central and Eastern Europe. Czech Journal of Social Sciences, Business and Economics 5(2):6-15. doi: 10.24984/cjssbe.2016.5.2.1

Czyżewski A, Smędzik-Ambroży K (2015) Specialization and diversification of agricultural production in the light of sustainable development. Journal of International Studies 8(2):63-73. doi: 10.14254/2071-8330.2015/8$2 / 6$

Institute for Economic Research and Policy Consulting (2014) Reitynh investytsiinoi pryvablyvosti rehioniv (2014) [The investment attractiveness of the regions]. Instytut ekonomichnykh doslidzhen ta politychnykh konsultatsii. http://www.ier.com.ua/files/Projects/2014.pdf. Accessed 18 May 2018

Kharlamova G (2014) Investment attractiveness of Ukrainian regions: rating assessment and marketing promotion. Journal of International Studies 7(1): 9-26. doi: 10.14254/2071-8330.2014/7-1/1

Litovkina OO (2015) Organization of investment activity in the region: problems and prospects. Scientific bulletin of Polissia 2 (2):59-62

Mantsevych Yu, Skupskyi R, Melnychuk L (2016) Novitnia paradyhma investytsiinykh protsesiv ahrarnoho sektoru ekonomiky [The latest paradigm of investment processes in the agrarian sector of the economy]. [Naukovi zapysky Instytutu zakonodavstva Verkhovnoi Rady Ukrainy] Scientific notes of the Institute of Legislation of the Verkhovna Rada of Ukraine 5:99-107

Mishenin Y, Koblianska I, Medvid V, Maistrenko Y (2018) Sustainable regional development policy formation: role of industrial ecology and logistics. Entrepreneurship and Sustainability Issues 6(1):329-341. doi: 10.9770/jesi.2018.6.1(20)

Newbery D, Pollitt MG, Ritz RA, Strielkowski W (2018) Market design for a high-renewables European electricity system. Renewable and Sustainable Energy Reviews 91:695-707. doi: 10.1016/j.rser.2018.04.025

Ponomarenko T, Zinchenko O, Khudoliei V, Prokopenko O, Pawliszczy D (2018) Formation of the investment environment in Ukraine in the context of European integration: an example of Poland. Investment Management and Financial Innovations 15 (1): 361-373. doi:10.21511/imfi.15(1).2018.30

Radovic D, Strielkowski W, Wang J, Cepel M, Rausser G (2017) Economic analysis of sustainable tourism: a case study of Nottingham. Transformations in Business \& Economics 16(2B):703-714

Ragulina Y V, Semenova E I, Zueva I A, Kletskova EV, Belkina E N (2018) Perspectives of solving the problems of regional development with the help of new internet technologies. Entrepreneurship and Sustainability Issues 5(4)890-898. doi:10.9770/jesi.2018.5.4(13)

Reiff M, Surmanová K, Balcerzak AP, Pietrzak MB (2016) Multiple criteria analysis of European Union agriculture. Journal of International Studies 9(3):62-74. doi:10.14254/2071-8330.2016/9-3/5

Skupskyi R, Anikieieva N (2016) Suchasna investytsiina polityka ahrarnykh pidpryiemstv: teoretychnyi kontekst formuvannia [Modern investment policy of agrarian enterprises: theoretical context of formation]. Ekonomika i finansy. Spetsvypusk. - Economy and finance. Special issue 1:108-117

Slobodianiuk N (2016) Analiz ta otsinka investytsiinoi pryvablyvosti rehioniv Ukrainy [Analysis and estimation of investment attractiveness of regions of Ukraine]. Hlobalni ta natsionalni problemy ekonomiky-Global and national problems of the economy 14:235-239

State Statistics Service of Ukraine (2018) Ofitsiinyi sait Derzhavnoi sluzhby statystyky Ukrainy [Official site of the State Statistics Service of Ukraine]. http://www.ukrstat.gov.ua. Accessed 15 May 2018

Sydor H (2015) Investytsiina pryvablyvist rehioniv. [Investment attractiveness of the regions.]. Stalyi rozvytok ekonomiky-Sustainable development of the economy 2 (27):184-189

Vakulich M, Kliuchnyk R (2018) Concept of investment climate management: models of monitoring and innovative implementation. Scientific bulletin of Polissia 1 (13) P1: 159-168. doi: 10.25140/2410-9576-2018-11(13)-159-168 
Zakharin S (2016) On formation of strategies guidelines for regions' investment development. Scientific bulletin of Polissia 2 (6):56-60

Zatonatska T (2016) Global trends in state investment policy and practice of their implementation in Ukraine. Economic Annals - XXI 156 (1-2): 26-30

Ziyadin S, Suieubayeva S, Kabasheva N, Moldazhanov M (2017) Economic rationale for the investment attractiveness of China at present. Economic Annals - XXI 163 (1-2 (1)): 35-40

Zubkov R (2017) Metodolohichni pidkhody do rozvytku ta otsinky investytsiino-innovatsiinoi materii rehionu [Methodological approaches to the development and evaluation of investment and innovation of the region]. Naukovyi visnyk Khersonskoho derzhavnoho universytetu: Ekonomichni nauky. - Scientific Herald of Kherson State University: Economic Sciences 22 P 2: 55-59 